doi:

\title{
Biochemical features of phoma-like fungi
}

Sokornova S.V. ${ }^{1}$, Shavarda A.L. ${ }^{2}$, Gusenkov E.A. ${ }^{3}$, Emelianov D.A. ${ }^{3}$, Frolova G.M. ${ }^{1}$

${ }^{1}$ All-Russian Institute of Plant Protection, St. Petersburg, Russia; ${ }^{2}$ Saint Petersburg State University, Research park, Centre for molecular and cell technologies, Russia; ${ }^{3}$ Saint-Petersburg State Institute of Technology, 190013, Russia

E-mail: svsokornova@vizr.spb.ru

Key message. Biochemical analysis of phoma-like fungi showed significant differences in the phosphatidic acid and glycoceramides levels and close values of phosphatidylcholine / phosphatidylethanolamine, trehalose, arabitol, mannitol, sorbitol levels.

Keywords: phospholipids, polyols, trehalose, phoma-like micromycetes, mycoherbicides

Phoma-like micromycetes are considered as the potential mycoherbicides for the biocontrol of perennial weed and invasive plants. Prediction of efficacity and stability bioherbicides in field, drying survival, wintering ability etc. is based on analysis of structural lipids, polyols and trehalose levels. [1-2]. The aim of this work is to analyze these compounds in the deep mycelium of phoma-like strains: Stagonospora cirsii C-211, Calophoma complanata 32.121, Didymella macrostoma 32.52 . The mycelium was grown on the sucrose-soy medium until the early stationary phase of growth. To the polar lipids analyze mycelium was extracted by modified method [3]. The HPTLC plate was developed in chloroform-methanol-water-25\% ammonia (65:30:4:2). Staining was carried out with a copper sulfate / sulfuric acid reagent in methanol under heating. The absorbance was measured at $550 \mathrm{~nm}$ [2]. To definition of the carbohydrate levels mycelium was extracted by $80 \%$ ethanol at $80 \mathrm{oC}$. Chromatography was carried out on a HPTLC plate silica gel 60 using n-butanol-i-propanol-acetic acid-2\% boric acid solution $(6: 14: 1: 3)$. Staining was carried out with the aniline diphenylamine $o$-phosphoric acid reagent under heating. The absorbance was measured at $370 \mathrm{~nm}$. Polyol acetate carbohydrate derivatives were analyzed using an Agilent 5975 (column: Agilent Technologies, HP-5ms, $30 \mathrm{~m}$ x $0.250 \mathrm{~mm}, 0.25 \mathrm{~mm}[1]$.

The phosphatidylcholine (PC), phosphatidylethanolamine (PE), phosphatidic acid (PA) and glucosylceramides (GC) was identified in the polar lipids fraction. The ratio and proportion of PC and PE was the same for the all strains. In the same time the $C$. complanata 32.121 mycelium contained one and a half times more PA and significantly less GC than other strains. PA is a key component of phospholipids homeostasis and a secondary messenger involved in intracellular signaling in eukaryotes. The PA levels in fungi usually does not exceed $1 \%$. This aspect would certainly require further study.

In all extracts was dominated by disaccharide trehalose and polyols: arabitol, mannitol and sorbitol. The assessment of the carbohydrate levels may be an additional criterion for predicting the stress resistance of mycogericides based on phoma-like micromycetes. This work was supported by RSF grant 16-16-00085.

\section{Биохимические особенности фомоидных микромицетов}

Сокорнова С.В. ${ }^{\text {, }, ~ Ш а в а р д а ~ А . Л . ~}{ }^{2}$, Гусенков Е.А. ${ }^{3}$, Емельянов Д.А. ${ }^{3}$, Фролова Г.М. ${ }^{\prime}$

${ }^{1}$ Всероссийский научно-исследовательский институт защиты растений, Санкт-Петербург, Россия; ${ }^{2}$ Санкт-Петербургский государственный университет, научный парк, РЦ «Развитие молекулярных и клеточных технологий», Санкт-Петербург, Россия; ${ }^{3}$ Санкт-Петербургский государственный технологический институт, Санкт-Петербург, Россия

\footnotetext{
Аннотация. Биохимический анализ фомоидных грибов показал достоверные различия содержсания фосфатидной кислоты и гликоцерамидов, близкие значения для фосфатидилхолина/ фосфатидилэтаноламина, трегалозы, арабитола, маннитола, сорбитола.
}

Ключевые слова: фосфолипиды, полиолы, трегалоза, фомоидные микромицеты, микогербиииды

Среди потенциальных микогербицидов, разрабатываемых для борьбы с многолетней сорной и инвазивной растительностью, есть фомоидные микромицеты. Прогноз эффективности и стабильности в полевых условиях, устойчивости к высушиванию, способности переносить зимовку и пр., может основываться на данных о содержании структурных липидов, полиолов и трегалозы [1-2]. Цель работы: анализ содержания этих соединений в глубинном мицелии штаммов фомоидных грибов: Stagonospora cirsii C211, Calophoma complanata 32.121, Didymella macrostoma 32.52. Мицелий выращивали на сахарозо-соевой среде до ранней стационарной фазы роста. Анализ полярных липидов проводили путем экстракции модифицированным методом [3], с последующим разделением на пластинах HPTLC Silica gel 60 F254 в системе хлороформ-метанол-вода-25\% аммиак (65:30:4:2), визуализацией реактивом сульфата меди при нагревании и детектировании при 550 нм [2]. Анализ углеводов мицелия проводили путем экстракции $80 \%$ этанолом при $80 \mathrm{oC}$. ВЭТСХ проводили в системе н-бутанол-изопропанол-уксусная кислота- $2 \%$ борная кислота $(6: 14: 1: 3)$. Окраску проводили реагентом анилин-дифениламин-фосфорная кислота при нагревании и детектировании при 370 нм. Полиолы анализировали в виде силильных производных на приборе Agilent с масс-селективным детектором 5975, колонкой HP-5MS, 30 м×0.25 мм [1]. В составе фракции полярных липидов идентифицировали фосфатидилхолин (ФХ), фосфатидилэтаноламин (ФЭ), фосфатидную кислоту (ФК) и гликоцерамиды (ГлЦер). Доля и соотношение ФХ и ФЭ были для всех штаммов одинаковы. В тоже время мицелий C. complanata 32.121 содержал в полтора раза больше ФК, чем другие штаммы, и существенно меньшее количество ГлЦер. ФК - ключевой компонент гомеостаза фосфолипидов и вторичный мессенджер клеточных процессов эукариот. Содержание ФК в грибах обычно не превышает $1 \%$, выявленный факт требует дальнейшего изучения.

Доминирующим дисахаридом во всех случаях была трегалоза, а полиолами - арабитол, маннитол и сорбитол. Оценка содержания этих углеводов может быть дополнительным критерием для прогнозирования стресс-устойчивости микогербицидов на основе фомоидных микромицетов. Работа поддержана грантом РНФ 16-16-00085.

1. Sokornova S, Frolova G, Shavarda A et al. / BIO Web of Conferences 2020, 18, 00028.

2. Фролова ГМ, Сокорнова СВ, Берестецкий АО / Прикл. биохимия и микробиология. 2019, 55 (5): 506-512.

3. Bligh EG, Dyer WJ / Can. J. Biochem. Physiol. 1959, 37:911-917. 